\title{
Application of the comet assay in erythrocytes of Oreochromis niloticus (Pisces): A methodological comparison
}

\author{
Cintya A. Christofoletti ${ }^{1}$, José Augusto O. David ${ }^{2}$ and Carmem S. Fontanetti ${ }^{1}$ \\ ${ }^{1}$ Departamento de Biologia, Instituto de Biociências, Universidade Estadual Paulista \\ “Júlio de Mesquita Filho”, Rio Claro, SP, Brazil. \\ ${ }^{2}$ Departamento de Genética, Instituto de Biociências, Universidade Federal do Pará, Belém, PA, Brazil.
}

\begin{abstract}
The present study applied the comet assay to erythrocytes of Oreochromis niloticus with the aim of improving protocols to detect DNA damage in these cells, by using two distinct $\mathrm{pHs}(\mathrm{pH}=12.1$ and $\mathrm{pH}>13)$ and evaluating whether there is a correspondence between silver and ethidium bromide staining. Comets were visually examined and, the frequency of cells with and without damage was obtained, as well as the distribution of classes and scores. By using the Kruskal-Wallis test, our results revealed that $\mathrm{pH} 12.1$ is more effective, although both $\mathrm{pHs}$ can be used. Our findings also suggest that silver staining can substitute ethidium bromide, an expensive and highly toxic stain that requires specific equipment for examination.
\end{abstract}

Key words: comet assay, ethidium bromide, silver staining, tilapia.

Received: April 2, 2008; Accepted: September 5, 2008.

The development of new methodologies and the application of more sensitive assays to detect genotoxicity in different samples have been the subject of several scientific studies on environmental monitoring (Al-Sabti and Metcalfe, 1995; Lemos et al., 2005). The Comet Assay, or single cell gel electrophoresis, is a sensitive genotoxicological method for assessing DNA damage in single cells, allowing for the quantification of DNA breaks and alkaline labile sites. Compared with other genotoxicity tests, the advantages of the comet assay are the detection of slight DNA damage, the low number of cells required, low cost, precision, ease of application, reproducibility, and short period of time to conduct the experiment (Belpaeme et al., 1998; Tice et al., 2000; Bücker et al., 2006).

This technique is the result of studies undertaken by Östling and Johanson, who developed the methodology of DNA electrophoresis in micro-gel, and those by Singh et al. (1988), who improved the technique. Currently, several international research groups have published recommendations describing protocols and criteria for the comet assay, aiming at establishing high standards to obtain valid, reproducible, and accurate data (Klaude et al., 1996; BrendlerSchwaab et al., 2005; Di-Paolo, 2006).

The comet assay has been successfully applied in erythrocytes of several fish species, thereby showing the

Send correspondence to Carmem S. Fontanetti. Departamento de Biologia, Instituto de Biociências, Universidade Estadual Paulista "Júlio de Mesquita Filho", Av. 24-A, 1515, 13506-900 Rio Claro, SP, Brazil. E-mail: fontanet@rc.unesp.br. sensitivity of the blood cells of these animals to genotoxic effects (Padrangi et al., 1995; Belpaeme et al., 1998; Gontijo et al., 2003). Thus, the aim of the present study was to apply the comet assay to erythrocytes of specimens of the fish Oreochromis niloticus, in order to improve protocols for analyzing DNA damage in these cells, by using two distinct $\mathrm{pHs}$, and evaluate whether there is a correspondence between silver and ethidium bromide staining.

For the bioassay, two $20 \mathrm{~L}$ aquaria were filled with water from an artesian well, this then being aerated for $48 \mathrm{~h}$ and maintained at a room temperature ranging from 20 to $23{ }^{\circ} \mathrm{C}$, prior to the experiment. Five specimens of Oreochromis niloticus (Perciformes, Cichilidae), commonly known as Nile tilapia, were placed in the aquaria (table 1). Fishes were obtained from a fish tank of the Institute of Biosciences of the São Paulo State University, Rio Claro campus. The fishes were not fed during the experiment and were exposed to a 14:10 h light/dark cycle, under constant aeration. These were then divided into two groups, treated and non-treated. Non-treated fishes were injected intraperitonially with saline solution $(30 \mathrm{~mL}$ of physiological solution $/ 50 \mathrm{~g}$ of fish) $72 \mathrm{~h}$ prior to the end of the experiment. The treated group received an intraperitonial injection of cyclosphosphamide $(20 \mathrm{mg} / \mathrm{mL})(30 \mathrm{~mL}$ of cyclosphosphamide $/ 50 \mathrm{~g}$ of fish), also $72 \mathrm{~h}$ prior to the end of the experiment.

The comet assay was undertaken according to Singh et al. (1988) and Villela et al. (2006), with certain modifications, as follows. Slides were previously covered with $1.5 \%$ 
Table 1 - Mean and standard deviation of the weight and size of fishes used in the comet assay for both treatments.

\begin{tabular}{lcc}
\hline Treatments & Weight $(\mathrm{g})$ & Size $(\mathrm{cm})$ \\
\hline Non-treated & $37.1 \pm 10.60$ & $13.24 \pm 1.66$ \\
Treated & $41.34 \pm 8.01$ & $13.98 \pm 0.82$ \\
\hline
\end{tabular}

normal melting point agarose. Cardiac punctures were performed and $0.3 \mathrm{~mL}$ of blood was drawn from the specimens. The assay was done in triplicate and later evaluated regarding the effect of different $\mathrm{pHs}$ and staining. After cardiac punctures, $5 \mu \mathrm{L}$ of the blood sample were diluted in $1000 \mu \mathrm{L}$ of PBS. $10 \mu \mathrm{L}$ of cell suspension with $120 \mu \mathrm{L}$ of $0.5 \%$ low melting point agarose at $37^{\circ} \mathrm{C}$, were layered on previously prepared slides, cover-slipped and placed in the refrigerator for $5 \mathrm{~min}$, for solidification of the gel. The cover-slips were then removed and the slides immersed in a freshly-prepared lysis solution $(1 \mathrm{~mL}$ of Triton-X 100 , $20 \mathrm{~mL}$ of DMSO and $79 \mathrm{~mL}$ of lysis stock solution: $2.5 \mathrm{M}$ $\mathrm{NaCl}, 100 \mathrm{mM}$ EDTA and $10 \mathrm{mM}$ Tris, $\mathrm{pH}$ 10.0-10.5) for a minimum of at least one hour and a maximum of two, at $4{ }^{\circ} \mathrm{C}$. After lysis, slides were transferred to a horizontal electrophoresis tank. For the first two runs, alkaline solution was added $(300 \mathrm{mM} \mathrm{NaOH}$ and $1 \mathrm{mM}$ EDTA, $\mathrm{pH}=12.1)$ for $20 \mathrm{~min}$. Upon completion of the relaxing time, slides were subjected to electrophoresis for $15 \mathrm{~min}$ at $21 \mathrm{~V}$ and $270 \mathrm{~mA}\left(0.8 \mathrm{~V} . \mathrm{cm}^{-1}\right)$. The same procedures were followed for the last run, although an alkaline buffer $(\mathrm{NaOH} 300 \mathrm{mM}$ and $1 \mathrm{mM}$ EDTA, $\mathrm{pH}>13$ ) was used in this case. All procedures were carried out under indirect light. After electrophoresis, slides were carefully removed from the tank. Neutralization was performed through three baths of $5 \mathrm{~min}$ with a neutral buffer $(0.4 \mathrm{M}$ Tris- $\mathrm{HCl}, \mathrm{pH}$ 7.5) to remove salts and detergents. Slides were then allowed to dry at room temperature.

For ethidium bromide staining (Figure 1A-C), slides were fixed with $100 \%$ ethanol for $10 \mathrm{~min}$ and allowed to dry at room temperature. These were then stained with an aqueous solution of ethidium bromide $(0.02 \mathrm{mg} / \mathrm{mL})$ before examination under a fluorescence microscope (Leica DMLB), filter B- $3^{4}$ (excitation: $\mathrm{i}=420 \mathrm{nM}$; barrier: $\mathrm{I}=520 \mathrm{nM})$, magnification 1000x.

For silver staining (Figure 1D-F), slides were immersed in a fixative solution (15\% trichloroacetic acid, $5 \%$ zinc sulfate, $5 \%$ glycerol), for $10 \mathrm{~min}$ in a vertical tank, rinsed three times with distilled water and allowed to dry overnight at room temperature. They were then rehydrated for $5 \mathrm{~min}$ with distilled water and stained with $36 \mathrm{~mL}$ of solution $\mathrm{A}$ ( $5 \%$ sodium carbonate) and $54 \mathrm{~mL}$ of solution $\mathrm{B}$ ( $0.1 \%$ ammonium nitrate, $0.1 \%$ silver nitrate, $0.1 \%$ silicotungstic acid, $0.15 \%$ formaldehyde, freshly prepared and in the dark) under constant shaking at $37^{\circ} \mathrm{C}$ for $10 \mathrm{~min}$, or until they became either gray or brown. After staining, the slides were washed twice with distilled water and immersed in a stop solution ( $1 \%$ acetic acid) for $5 \mathrm{~min}$, to be

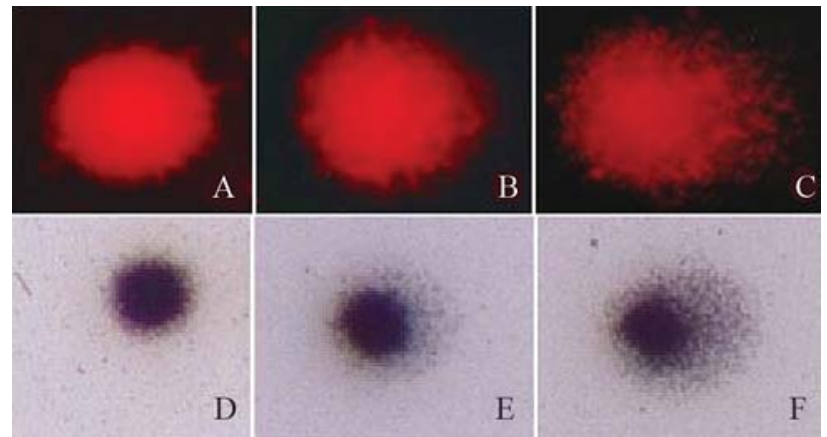

Figure 1 - Comet assay applied in erythrocytes of $O$. niloticus using $\mathrm{pH}$ 12.1 stained with ethidium bromide (A. Class 0, B. Class 1, C. Class 2) and silver (D. Class 0, E. Class 1, F. Class 2).

then washed again three times with distilled water and after allowed to dry at room temperature. They were later examined under a light microscope at 400x magnification.

One hundred comets per slide were examined using visual classification based on the migration of DNA fragments of the nucleus. Comets were classified into four classes: class 0 (no damage), class 1 (little damage), class 2 (medium damage), and class 3 (extensive damage). Data were presented as the frequency of damaged cells, class distribution, and damage scores, calculated as the sum of cells in each class and the total number of cells in each class multiplied by the number of classes (0-3). Scores ranged from zero (all cells with no damage - 0x100) to 300 (all cells with maximum damage $3 \times 100$ ), according to Rigonato et al. (2005). Statistical analysis was performed using the Kruskal-Wallis test, with the level of significance set at $p<0.05$.

The results obtained here for the comet assay in Oreochromis niloticus erythrocytes showed similar images (Figure 1) and score (Table 2) for both staining procedures when $\mathrm{pH} 12.1$ was used in the assay.

In the untreated group, a cell statistical difference was observed between $\mathrm{pH} 12.1$ and $\mathrm{pH}>13$ (Table 2). When $\mathrm{pH}>13$ was used in this group, the number of class 0 comets decreased while class 1 comets revealed a significant increase (Table 2). This can probably be due to, the expression of alkali-labile sites that occur only with $\mathrm{pH}>13$.

Similar levels of damage were registered in treated group cells at $\mathrm{pH} 12.1$ and $\mathrm{pH}>13$ (Table 2). The effect of treatment could be measured with both staining and $\mathrm{pH}$, although the difference between treated and untreated groups was greater at $\mathrm{pH} 12.1$, probably because of the expression of different DNA damage in $\mathrm{pH}>13$.

According to Padrangi et al. (1995) and Lemos et al. (2005), different tissues of aquatic organisms can be used for the comet assay. However, in most cases, erythrocytes have been used as target-cells, as they require small volumes that can be obtained through a non-damaging technique and cell dissociation is not needed (Belpaeme et al., 1998). Gontijo et al. (2003) also applied the comet assay to erythrocytes of Oreochromis niloticus to assess possible 
Table 2 - Average number of cells with comet, distribution of classes and damage scores (mean and standard deviation) for the two treatments using two $\mathrm{pHs}$ and forms of staining.

\begin{tabular}{|c|c|c|c|c|c|c|c|c|c|}
\hline \multirow[t]{2}{*}{ Treatments } & \multirow[t]{2}{*}{$\mathrm{pHs}$} & \multirow[t]{2}{*}{ Staining } & \multirow[t]{2}{*}{ NA } & \multirow[t]{2}{*}{ Comets } & \multicolumn{4}{|c|}{ Classes } & \multirow[t]{2}{*}{ Score } \\
\hline & & & & & 0 & 1 & 2 & 3 & \\
\hline \multirow[t]{3}{*}{ Non-treated } & 12.1 & silver & 500 & $10.6 \pm 1.4^{* \mathrm{a}, \mathrm{b}}$ & $89.2 \pm 1.4^{* \mathrm{c}}$ & $9.4 \pm 0.8^{* \mathrm{~d}}$ & $1.2 \pm 0.4$ & 0 & $11.8 \pm 1.48^{* \mathrm{a}, \mathrm{b}}$ \\
\hline & & ethidium bromide & 500 & $18.8 \pm 1.92^{* a}$ & $81.4 \pm 1.6$ & $18.6 \pm 1.6$ & $0.2 \pm 0.4$ & 0 & $19 \pm 2.2^{* a}$ \\
\hline & $>13$ & silver & 500 & $46.25 \pm 11.20^{* \mathrm{~b}}$ & $54.2 \pm 10.2^{* \mathrm{c}}$ & $39 \pm 10.09^{* d}$ & $4.75 \pm 1.25$ & $2.5 \pm 1.2$ & $56 \pm 13.31^{* b}$ \\
\hline \multirow[t]{3}{*}{ Treated } & 12.1 & silver & 500 & $81.2 \pm 6.45$ & $18.8 \pm 6.4$ & $79 \pm 5.8$ & $2.2 \pm 1.7$ & 0 & $83.4 \pm 7.4$ \\
\hline & & ethidium bromide & 500 & $87 \pm 3.53$ & $15 \pm 1.5$ & $86.2 \pm 3.2$ & $0.8 \pm 0.8$ & 0 & $87.8 \pm 3.9$ \\
\hline & $>13$ & silver & 500 & $87.8 \pm 6.97$ & $12.2 \pm 6.9$ & $67 \pm 13.5$ & $14.6 \pm 9.9$ & $6.2 \pm 2.2$ & $108.8 \pm 9.20$ \\
\hline
\end{tabular}

*Identical letters: significant difference using the Kruskal-Wallis test $(\mathrm{p}<0,05)$.

NA: total nucleoids analyzed.

modulation of induced DNA damage by benzocaine, in erythrocytes exposed to two known mutagens, (methyl methanesulfonate and hydrogen peroxide). Their findings suggested that benzocaine does not interfere with comet assay results and can be recommended for the welfare of the animal, thus preventing stress.

Souza and Fontanetti (2007) used erythrocytes of $O$. niloticus for the comet assay to detect possible genotoxicants in the waters of the Paraíba do Sul River in an area affected by an oil refinery. The authors concluded that substances with genotoxic potential were present in the waters of the river, as a frequency increase in class 2 and 3 nucleoids was observed in all the months of collection.

According to Belpaeme et al. (1998), the comet assay can also be used to complement studies of chromosome aberrations, micronuclei, and sister chromatid exchanges. Our findings revealed that blood cells of $O$. niloticus used in the comet assay can be used as genotoxic indicators, thus constituting an efficient, fast, and sensitive method to detect DNA damages in these cells.

Since being described, single cell gel electrophoresis has been used by researchers in a wide variety of organisms and tissues, thereby improving its usefulness. Thus, to better understand the effects of different $\mathrm{pHs}$ on the erythrocytes of tilapias, certain changes were made, based on studies by Tice et al. (2000), Gontijo et al. (2003) and David (2007), using $\mathrm{pH} \mathrm{12.1,} \mathrm{unwinding} \mathrm{time} \mathrm{equivalent} \mathrm{to}$ $20 \mathrm{~min}$ and electrophoresis time of $15 \mathrm{~min}, 21 \mathrm{~V}$ and $270 \mathrm{~mA}$. pH variation during the lysis and electrophoresis steps affect the type of DNA breaks that can be detected, as DNA denatures and unwinds at pHs of around 12, due to breaks in hydrogen bridges between DNA strands (Kohn, 1991).

At $\mathrm{pH} 12.3$, breaks in the double and single strands are detected, as well as alkali-labile sites or abasic sites (Lee and Steinert, 2003). According to Tice et al. (2000), $\mathrm{pH}>13$ is widely used to maximize the expression of alkali-labile sites and single-strand breaks and thus it is the most recommended, especially for vertebrate cells. However, it is worth pointing out that there is a wide variety of
DNA lesions. Among these, single-strand breaks, do not give rise to drastic effects, as they are quickly repaired, whereas double stranded DNA breaks are much more severe and have much more complex repair pathways (Gontijo et al., 2003; Moller, 2006; David, 2007).

Di-Paolo (2006) evaluated the different exposure times of erythrocytes in snooks during the various steps in lysis and electrophoresis, and observed that there was a gradual increase in the intensity of DNA migration due to the effects from an increase in voltage of electrophoresis on the morphology of comets. The author also concluded that the best results were obtained at $\mathrm{pH} 12.6$ and $\mathrm{pH}>13$, under the following conditions: $10 \mathrm{~min}$ for unwinding and, $20 \mathrm{~min}$ for electrophoresis at $0.8 \mathrm{~V} / \mathrm{cm}$ and $300 \mathrm{~mA}$, thereby indicating the suitability of the assay for measuring damage in the blood cells of snooks.

Our results revealed that $\mathrm{pH} 12.1$ as well as $\mathrm{pH}>13$ are effective for the comet assay in tilapia erythrocytes. Although many authors, such as Tice et al. (2000) and Gontijo et al. (2003) suggested a $\mathrm{pH}>13$ for both vertebrate cells and $O$. niloticus, $\mathrm{pH} 12.1$ was the most efficient in this study, as there was a greater difference between treated and untreated cells on using $\mathrm{pH} 12.1$ when compared to $\mathrm{pH}>13$ (Table 2).

Ethidium bromide is traditionally used for staining materials examined by fluorescence. However, this dye has certain negative aspects, such as its toxic and mutagenic effects, the need for specific equipment and the short duration of staining. Silver staining, on the other hand, has been described as a good alternative for the comet assay, demonstrating high sensitivity when compared to ethidium bromide (Reinhardt-Poulin et al., 2000; Di-Paolo, 2006).

Di-Paolo (2006) applied silver staining in a comet assay on the blood cells of snooks and found high sensitivity when visually examining comets, as this is a fast and simple method that can be observed under the light microscope. Villela et al. (2006) obtained similar results in a study undertaken with the bivalve Limnoperna fortune when using different concentrations of copper sulfate and pentachlorophenol. 
Garcia et al. (2007) described a protocol for silver staining when using the comet assay in human lymphocytes exposed to gamma radiation, and obtained a significant percentage of DNA in the tail of silver-stained comets, very similar to those obtained by fluorescence staining. Other parameters of comets, such as length and momentum of the tail, were also quantified using conventional microcopy and Internet software.

The results obtained in our study showed that both stains were efficient. Silver staining, however is recommended, as it is less toxic than ethidium bromide, does not require specific equipment for analysis, and provides long lasting staining.

Thus, this study suggests that erythrocytes of Oreochromis niloticus are good genotoxicity indicators through the comet assay, an efficient, fast, and sensitive method to detect DNA damage. Our data also revealed that $\mathrm{pH} 12.1$ is the best, although both $\mathrm{pHs}, 12.1$ and $\mathrm{pH}>13$ can be used with adaptations under electrophoresis conditions. Moreover, silver staining is recommended in preference to ethidium bromide.

\section{Acknowledgments}

The authors are thankful to Dr. Dejanira Franceschi de Angelis of the Laboratory of Water Toxicity, Department of Biochemistry and Microbiology of the Institute of Biology of UNESP-Rio Claro/SP for technical support, to FUNDUNESP (Foundation for the Development of the UNESP) and to CNPq (National Council for Scientific and Technological Development) for financial support.

\section{References}

Al-Sabti K and Metcalfe CD (1995) Fish micronuclei for assessing genotoxicity in water. Mutat Res 343:121-135.

Belpaeme K, Cooreman Kand, Kirsch-Volders M (1998) Development and validation of the in vivo alkaline comet assay for detecting genomic damage in marine flatfish. Mutat Res Genet Toxicol Environ Mutagen 415:167-184.

Brendler-Schwaab S, Hartmann A, Pfuhler S and Speit G (2005) The in vivo comet assay: Use and status in genotoxicity testing. Mutagenesis 20:245-254.

Bücker A, Carvalho W and Alves-Gomes JA (2006) Avaliação da mutagênese e genotoxicidade em Eigenmannia virescens (Teleostei, Gymnotiformes) expostos ao benzeno. Acta Amazônia 36:357-364.

Garcia O, Romero I, Gónzalez JE and Mandina T (2007) Measurements of DNA on silver stained comets using free Internet software. Mutat Res 627:186-190.

Gontijo AMMC, Barreto RE, Speit G, Reyes VAV, Volpato GL and Salvadori DMF (2003) Anesthesia of fish with benzocaine does not interfere with comet assay results. Mutat Res 534:165-172.

Klaude M, Eriksson S, Nygren J and Ahnström G (1996) The comet assay: Mechanisms and technical considerations. Mutat Res 363:89-96.
Kohn KW (1991) Principles and practice of DNA filter elution. Pharmacol Ther 49:55-77.

Lee RF and Steinert S (2003) Use of the single cell gel electrophoresis/comet assay for detecting DNA damage in aquatic (marine and freshwater) animals. Mutat Res 544:43-64.

Lemos NG, Dias AL, Silva-Souza AT and Mantovani MS (2005) Evaluation of environmental waters using the comet assay in Tilapia rendalli. Environ Toxicol Pharmacol 19:197-201.

Moller P (2006) The alkaline comet assay: Towards validation in biomonitoring of DNA damaging exposures. Pharmacol Toxicol 98:336-345.

Padrangi R, Petras M, Ralph S and Vrzoc M (1995) Alkaline single cell gel (comet) assay and genotoxicity monitoring using bullheads and carp. Environ Mol Mutagen 26:345-356.

Reinhardt-Poulin P, McLean JR, Deslauriers Y, Gorman W, Cabat S and Rouabhia M (2000) The use of silver-stained "comets" to visualize DNA damage and repair in normal and Xeroderma pigmentosum fibroblasts after exposure to simulated solar radiation. Photochem Photobiol 71:422-425.

Rigonato J, Mantovani MS and Jordão BQ (2005) Comet assay comparison of different Corbicula fluminea (Mollusca) tissues for the detection of genotoxicity. Genet Mol Biol 28:464-468.

Singh NP, McCoy MT, Tice RR and Schneider EL (1988) A simple technique for quantification of low levels of DNA damage in individual cells. Exp Cell Res 175:184-191.

Tice RR, Agurell E, Anderson D, Burlinson B, Hartmann A, Kobayashi H, Miyamae Y, Rojas E, Ryu JC and Sasaki YF (2000) Single cell gel/comet assay: Guidelines for in vitro and in vivo genetic toxicology testing. Environ Mol Mutagen 35:206-221.

Villela IV, Oliveira IM, Silva J and Henriques JAP (2006) DNA damage and repair in haemolynph cells of golden mussel (Limnoperna fortunei) exposed to environmental contaminants. Mutat Res 605:78-86.

\section{Internet Resources}

David JAO (2007) Estudo de Mytella falcata (Mollusca, Bivalvia) como indicadora de efeitos genotóxicos e citotóxicos no estuário de Santos, SP (PhD Thesis, UNESP, Rio Claro, 2007), http://www.athena.biblioteca.unesp.br/exlibris/bd/brc/3300 4137046P4/2007/david_jao_dr_rcla.pdf (January 25, 2008)

Di-Paolo C (2006) Aplicação do ensaio do cometa a estudo de danos ao DNA de robalos, Centropomus parallelus (Poey, 1860), expostos à $\beta$-naftoflavona (Master Thesis, USP, São Paulo, 2006), http://www.teses.usp.br/teses/disponiveis/21/21131/tde-17 102006-154149/ (January 25, 2008)

Souza TS and Fontanetti CS (2007) Ensaio do cometa para avaliação das águas do rio Paraíba do Sul, numa área sob influência de uma refinaria de petróleo. $4^{\circ}$ Congresso Brasileiro de $\mathrm{P} \& \mathrm{D}$ em Petróleo e Gás-PDPETRO, 2007, Campinas, p. 1-10, http://www.portalabpg.org.br/PDPetro/4/resumos/4PDPET RO_6_2_0018-1.pdf (August 5, 2008).

\section{Associate Editor: Catarina S. Takahashi}

License information: This is an open-access article distributed under the terms of the Creative Commons Attribution License, which permits unrestricted use, distribution, and reproduction in any medium, provided the original work is properly cited. 